\title{
Numerical Evaluation of the Performance for a Different Structural System Against Seismic Movements in Multi-Storey Reinforced Concrete Buildings
}

\author{
Miraç Mesutoğlu*1(D, Hatip Tok 1 (D) \\ 1Kahramanmaraş Sütçü İmam University, Faculty of Engineering and Architecture, Department of Civil Engineering, \\ Kahramanmaraş, Turkey.
}

\author{
Keywords \\ Braced frame system \\ Earthquakes \\ Multi-storey buildings \\ SAP2000 \\ Shear wall system
}

\begin{abstract}
In recent years, the devastating earthquakes that occurred in many parts of the world have made it even more important the design of earthquake-resistant structures and earthquake performance assessment of existing structures. When innovative systems are examined in building design, it is seen that depending on the developments in recent years, performance-based designs come to the fore in addition to force-based design. This paper provides a new design method's model for multi-storey buildings that can achieve the same resistance against seismic movements by using less concrete and reinforcement using the SAP2000. Modeling studies of the braced frame system used in steel structures for reinforced concrete and multi-storey buildings with different heights was carried out according to 2019 Turkey Building Earthquake Code (TBEC) and Turkish Standard 498 (TS 498). In the modeling studies carried out in reinforced concrete and 20, 30 and 40 storey buildings, the same strength was tried to be obtained with less concrete and reinforcement. As a result of the studies, it has been seen that this new system, which is determined for all models, is an advantageous and performance system in terms of both volume, weight and stabilization compared to reinforced concrete structures with shear wall frame system.
\end{abstract}

\section{INTRODUCTION}

Earthquakes that have occurred in different parts of the world from past to present have shown that most buildings are insufficient against large seismic movements. Scientists and researchers have been working to improve the seismic performance of structures for many years (KeerthiGowda and Tajoddeen, 2014).

Earthquakes in the world in recent years have made it necessary to design structures resistant to such a live load, especially to evaluate the earthquake performance of multi-storey buildings (Nath et al., 2018).

Most of the national and international earthquake resistance codes are based on adaptive structures that can absorb and dissipate sizeable amounts of seismic energy through plastic deformations (Phocas and Pamboris, 2009).
Most of the tallest buildings in the world have a steel structure system due to its high strength-toweight ratio, ease of assembly and field installation, economy of shipping to the site, availability of various strength levels, and wider choice of sections (Kayvani, 2014).

Reinforced concrete structures are especially preferred because the material used is easy to supply and economical. However, a durable structure should be able to withstand the effects of gravity or meteorological forces acting on any structure, regardless of the material used.

Columns, beams, shear walls and floors form the structural system in a building. The structural system that keeps the building up must be in a condition resistant to live loads such as earthquakes (Li, 2010).

There are many studies in the literature on different situations of structural systems. Innovative 
"combined with advanced fire protection, corrosion resistance, fabrication and assembly techniques, advanced analytical techniques made possible by the use of computers (Kovacevic and Dzidic, 2018).

In this study, modeling studies of braced frame system used in the steel structures were made for buildings with multi-storey reinforced concrete structure, considering in 2018 Turkey Building Earthquake Code (TBEC) and Turkish Standard 498 (TS 498).

The obtained model results were compared with the shear wall frame system used in reinforced concrete structures in terms of seismic performance.

SAP2000 finite element software was used in modeling studies of this system, which was not used in reinforced concrete structures before in general.

As a result of the modeling studies, it has been tried to obtain better strength results against seismic forces in reinforced concrete and buildings with 20 , 30 and 40 floors compared to the shear wall system.

\section{METHOD}

In the study, in order to show that braced frame systems are more advantageous than shear wall frame systems in terms of performance, shear wall frame and braced frame systems of 3 different building structures (20-30-40 storey) of the same dimensions were modeled in SAP2000 program and their performances were compared.

\subsection{Modeling Procedure}

While creating the system model, the finite elements representing parts of the structure such as beams, columns, etc., such as structural elements, curtains, walls, flooring, were modeled as shell structural elements.

Elastic or nonlinear joints and springs at the node points or supports, the system model was created using the template systems included in the SAP2000 software.

Model geometry was designed in AutoCAD program for all buildings $(20,30$ and 40 storey buildings) and transferred into SAP2000 program.

In SAP 2000, joints are generated automatically by the program. While creating the model geometry, six axes were kept available for all buildings at intervals of 6 meters in $+x$ and $+y$ directions. The floor height is modeled as $3.3 \mathrm{~m}$ in all buildings (Figure 1-3).

The buildings must be designed in a way that they can safely carry the fixed and live loads, wind, soil pressure, water, heat and earthquake forces on them. At this stage, it is compulsory to make calculations in accordance with standards and regulations (TBEC, 2018).

In the study, since there is no specific location for the modeled buildings with different heights, analyzes were made using the SAP2000 program standard data. In the model, $S$ s and $S_{1}$ values were determined on the Afad Earthquake Hazard Map
(Figure 4). The ground class for the buildings was taken from the ground study report. Using of the 2018 Turkey Building Earthquake Code, system coefficients of type D and I is entered as an input parameter.

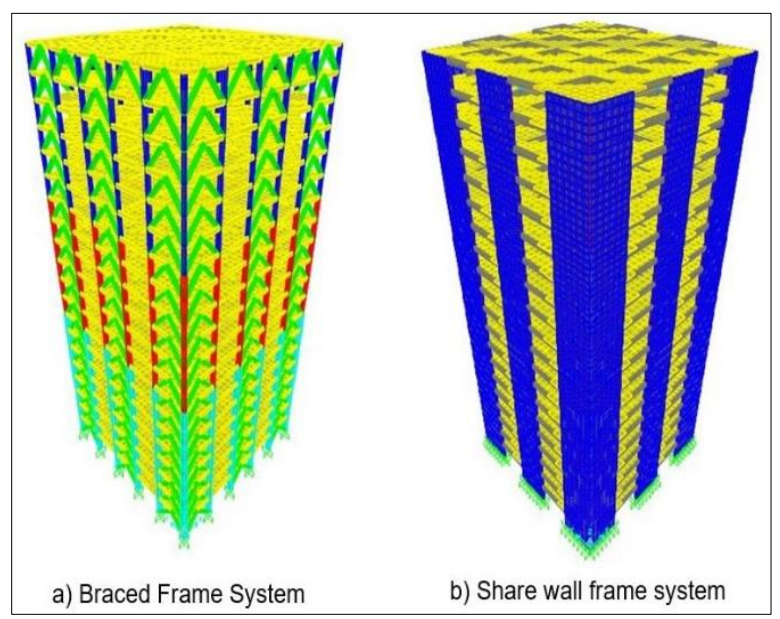

Figure 1. 3D view of shear wall system and braced system model for 20 -storey building model

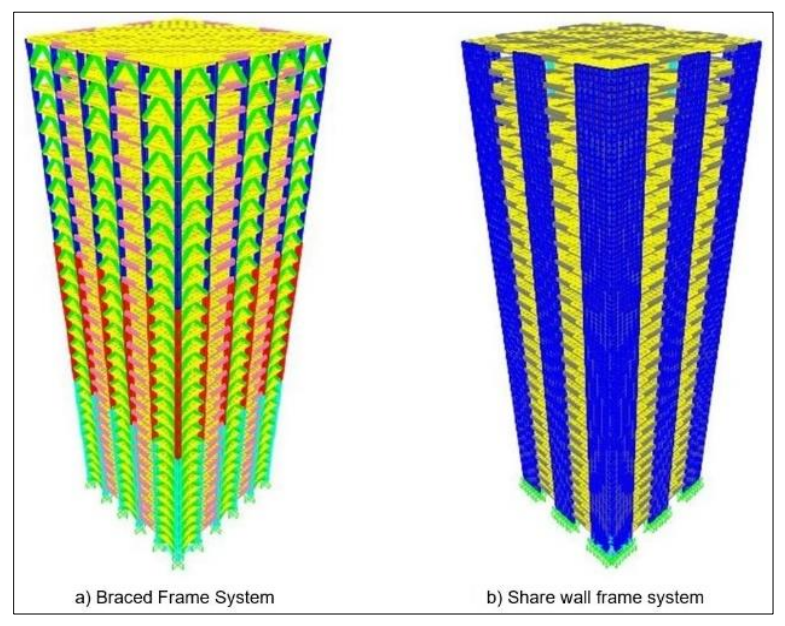

Figure 2. 3D view of shear wall system and braced system model for 30-storey building model

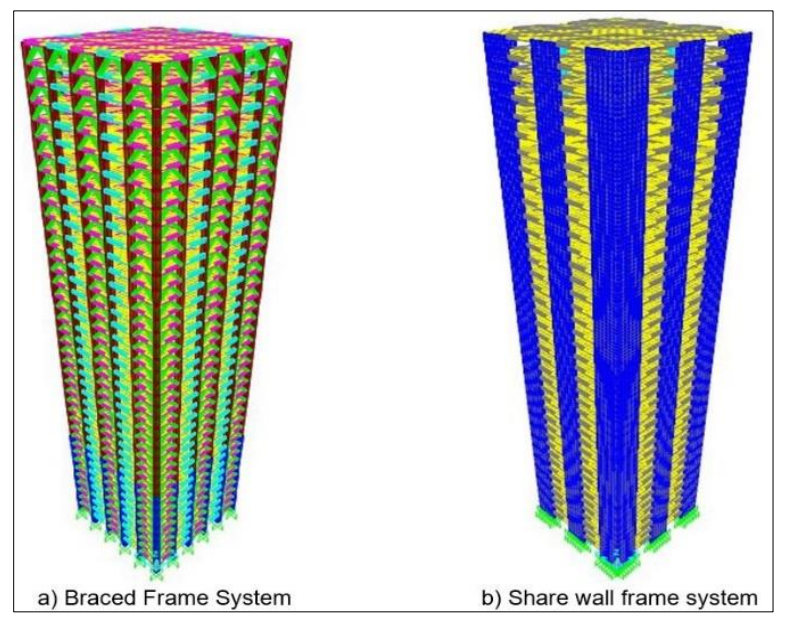

Figure 3. 3D view of shear wall system and braced system model for 40-storey building model 
According to TS-498, the characteristic live load is defined as $2 \mathrm{kN} / \mathrm{m}^{2}$ on each floor in all building models with different floor heights. The combination of the earthquake effect with other effects is defined in the equations (Equation 1 and equation 2) specified in 2018 TBEC and a total of 64 combinations based on the structural system.

$$
\begin{aligned}
& G+Q+0.2 S+E_{d}^{(H)}+0.3 E_{d}^{(Z)} \\
& 0.9 G+H+E_{d}^{(H)}-0.3 E_{d}^{(Z)}
\end{aligned}
$$

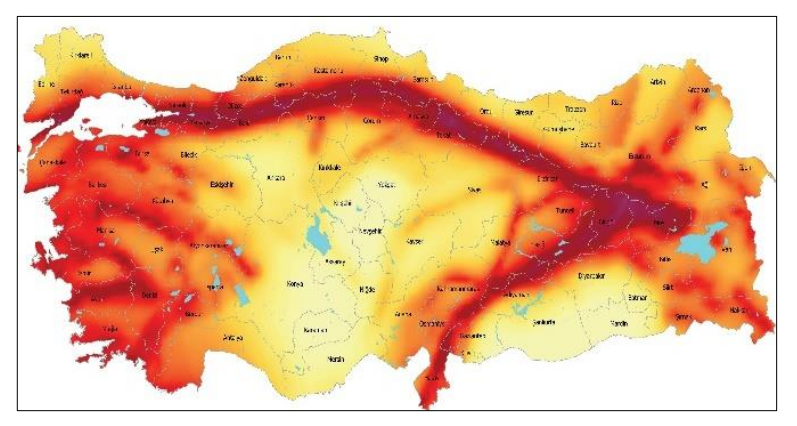

Figure 4. Earthquake hazard map of Turkey (AFAD, 2018)

For all the buildings modeled, linear analysis was chosen as the analysis type in all load classes. In order to obtain the mode shapes of the model and to provide relative displacements, the displacements of the column peaks at the closest position to the center of gravity of the structure were read for each floor.

\subsection{Assumptions and Limitations in the Models}

Some of the assumptions and limitations of the modeling studies are given below.

The compared buildings in the model studies are assumed to be in the 1st degree earthquake zone. It is assumed that the intended use of the modeled buildings is residential.

Considering to the 2018 Turkey Building Earthquake Code and Turkish Standard-TS498, the following values are used as input parameters in the model analysis (Table 1).

Table 1. Input parameters used in modeling studies

\begin{tabular}{|l|l|l|l|}
\hline Input Parameters & $\begin{array}{l}\text { 20-Storey } \\
\text { Building }\end{array}$ & $\begin{array}{l}\text { 30-Storey } \\
\text { Building }\end{array}$ & $\begin{array}{l}\text { 40-Storey } \\
\text { Building }\end{array}$ \\
\hline $\begin{array}{l}\text { Building Usage } \\
\text { Classification }\end{array}$ & 3 & 3 & 3 \\
\hline $\begin{array}{l}\text { Earthquake } \\
\text { Design Class }\end{array}$ & 1 & 1 & 1 \\
\hline $\begin{array}{l}\text { Building Importance } \\
\text { Factor }\end{array}$ & 1 & 1 & 1 \\
\hline $\begin{array}{l}\text { Building } \\
\text { Height Class }\end{array}$ & 2 & 1 & 1 \\
\hline Concrete Class & $\mathrm{C} 35 / 45$ & $\mathrm{C} 35 / 45$ & $\mathrm{C} 35 / 45$ \\
\hline Steel Class & $\mathrm{S} 420$ & $\mathrm{~S} 420$ & $\mathrm{~S} 420$ \\
\hline Floor Load $\left(\mathrm{kN} / \mathrm{m}^{2}\right)$ & 2 & 2 & 2 \\
\hline
\end{tabular}

\section{RESEARCH RESULTS}

The variation of the storey displacement values obtained as a result of the model analysis carried out in the study is presented exemplarily for 20-storey buildings (Table 2 and 3 ).

According to the 2018 Turkey Earthquake Building Code, the relative floor displacement in other words interstory drift is expressed as the difference of displacements between two consecutive times for a random column or wall (TBEC, 2018).

In the model analysis, the relative floor displacement calculated in columns and shear walls for each storey in the direction of the earthquake were examined. (Table 2 and 3).

Table 2. Displacement and relative floor displacement values for 20 -storey building model shear wall frame system.

\begin{tabular}{|c|c|c|c|c|}
\hline \multirow{2}{*}{$\begin{array}{c}\text { Floors } \\
\text { (Fl.) }\end{array}$} & \multicolumn{4}{|c|}{ Shear Wall Frame System } \\
\cline { 2 - 5 } & Displacement $\delta(\mathrm{m})$ & \multicolumn{2}{c|}{$\begin{array}{c}\text { Relative Floor } \\
\text { Displacement } \Delta \delta(\mathrm{m})\end{array}$} \\
\cline { 2 - 5 } & Ex (m) & Ey (m) & Ex (m) & Ey (m) \\
\hline Fl.-20 & 0,046935 & 0,047835 & 0,002559 & 0,002616 \\
\hline Fl.-19 & 0,044376 & 0,045219 & 0,002611 & 0,002667 \\
\hline Fl.-18 & 0,041765 & 0,042552 & 0,002660 & 0,002716 \\
\hline Fl.-17 & 0,039105 & 0,039836 & 0,002714 & 0,002771 \\
\hline Fl.-16 & 0,036391 & 0,037065 & 0,002768 & 0,002825 \\
\hline Fl.-15 & 0,033623 & 0,034240 & 0,002815 & 0,002873 \\
\hline Fl.-14 & 0,030808 & 0,031367 & 0,002853 & 0,002910 \\
\hline Fl.-13 & 0,027955 & 0,028457 & 0,002876 & 0,002931 \\
\hline Fl.-12 & 0,025079 & 0,025526 & 0,002878 & 0,002934 \\
\hline Fl.-11 & 0,022201 & 0,022592 & 0,002859 & 0,002913 \\
\hline Fl.-10 & 0,019342 & 0,019679 & 0,002813 & 0,002864 \\
\hline Fl.-9 & 0,016529 & 0,016815 & 0,002734 & 0,002784 \\
\hline Fl.-8 & 0,013795 & 0,014031 & 0,002620 & 0,002667 \\
\hline Fl.-7 & 0,011175 & 0,011364 & 0,002468 & 0,002511 \\
\hline Fl.-6 & 0,008707 & 0,008853 & 0,002270 & 0,002309 \\
\hline Fl.-5 & 0,006437 & 0,006544 & 0,002024 & 0,002059 \\
\hline Fl.-4 & 0,004413 & 0,004485 & 0,001717 & 0,001745 \\
\hline Fl.-3 & 0,002696 & 0,002740 & 0,001359 & 0,001381 \\
\hline Fl.-2 & 0,001337 & 0,001359 & 0,000929 & 0,000945 \\
\hline Fl.-1 & 0,000408 & 0,000414 & 0,000408 & 0,000414 \\
\hline
\end{tabular}


Table 3. Displacement and relative floor displacement values for 20-storey building model braced frame system

\begin{tabular}{|c|c|c|c|c|}
\hline \multirow{2}{*}{$\begin{array}{c}\text { Floors } \\
\text { (Fl.) }\end{array}$} & \multicolumn{4}{|c|}{ Braced Frame System } \\
\cline { 2 - 5 } & Displacement $\delta(\mathrm{m})$ & \multicolumn{2}{c|}{$\begin{array}{c}\text { Relative Floor } \\
\text { Displacement } \Delta \delta(\mathrm{m})\end{array}$} \\
\cline { 2 - 5 } & Ex (m) & Ey (m) & Ex (m) & Ey $(\mathrm{m})$ \\
\hline Fl.-20 & 0,046935 & 0,047835 & 0,002559 & 0,002616 \\
\hline Fl.-19 & 0,044376 & 0,045219 & 0,002611 & 0,002667 \\
\hline Fl.-18 & 0,041765 & 0,042552 & 0,002660 & 0,002716 \\
\hline Fl.-17 & 0,039105 & 0,039836 & 0,002714 & 0,002771 \\
\hline Fl.-16 & 0,036391 & 0,037065 & 0,002768 & 0,002825 \\
\hline Fl.-15 & 0,033623 & 0,034240 & 0,002815 & 0,002873 \\
\hline Fl.-14 & 0,030808 & 0,031367 & 0,002853 & 0,002910 \\
\hline Fl.-13 & 0,027955 & 0,028457 & 0,002876 & 0,002931 \\
\hline Fl.-12 & 0,025079 & 0,025526 & 0,002878 & 0,002934 \\
\hline Fl.-11 & 0,022201 & 0,022592 & 0,002859 & 0,002913 \\
\hline Fl.-10 & 0,019342 & 0,019679 & 0,002813 & 0,002864 \\
\hline Fl.-9 & 0,016529 & 0,016815 & 0,002734 & 0,002784 \\
\hline Fl.-8 & 0,013795 & 0,014031 & 0,002620 & 0,002667 \\
\hline Fl.-7 & 0,011175 & 0,011364 & 0,002468 & 0,002511 \\
\hline Fl.-6 & 0,008707 & 0,008853 & 0,002270 & 0,002309 \\
\hline Fl.-5 & 0,006437 & 0,006544 & 0,002024 & 0,002059 \\
\hline Fl.-4 & 0,004413 & 0,004485 & 0,001717 & 0,001745 \\
\hline Fl.-3 & 0,002696 & 0,002740 & 0,001359 & 0,001381 \\
\hline Fl.-2 & 0,001337 & 0,001359 & 0,000929 & 0,000945 \\
\hline Fl.-1 & 0,000408 & 0,000414 & 0,000408 & 0,000414 \\
\hline
\end{tabular}

The graphs presented in Figure 5 and 6 were created using the table 2 and table 3 values obtained from the modeling studies. These graphs show the displacement values in the $\mathrm{x}$ directions for each floor of two different 20-storey reinforced concrete buildings modeled using the braced system and the shear wall frame system (Figure 5 and 6 ).

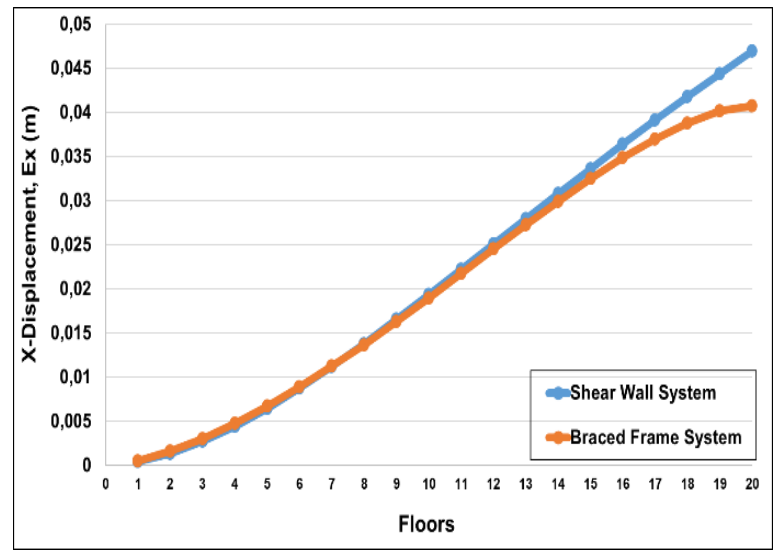

Figure 5. Graph of displacement values in $\mathrm{x}$ direction for each floor in 20-storey building models

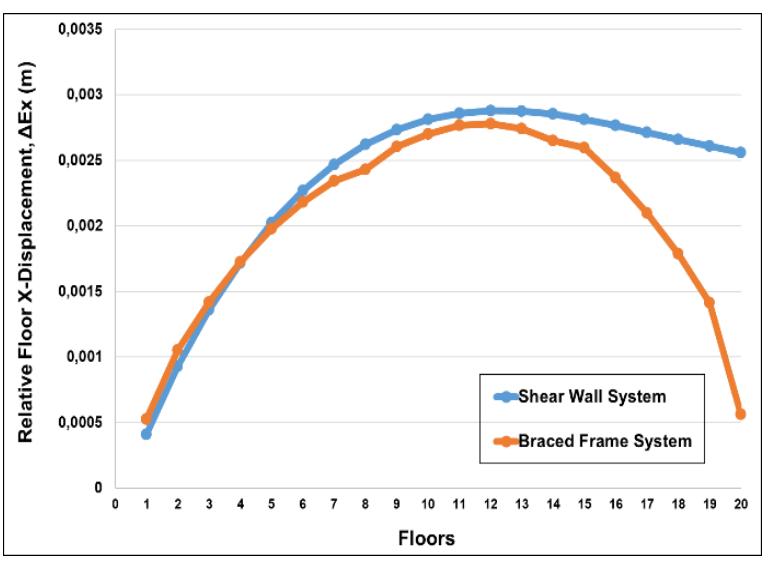

Figure 6. Graph of relative floor displacement values in $\mathrm{x}$ direction for each floor in 20-storey building models

Considering Figure 5 and 6 , it is seen that the braced frame system performs better than the shear wall system in both graphs.

The graphs of the comparisons in the analysis of the shear wall frame system and braced frame systems for 30-storey buildings are shown in Figure 7 and 8.

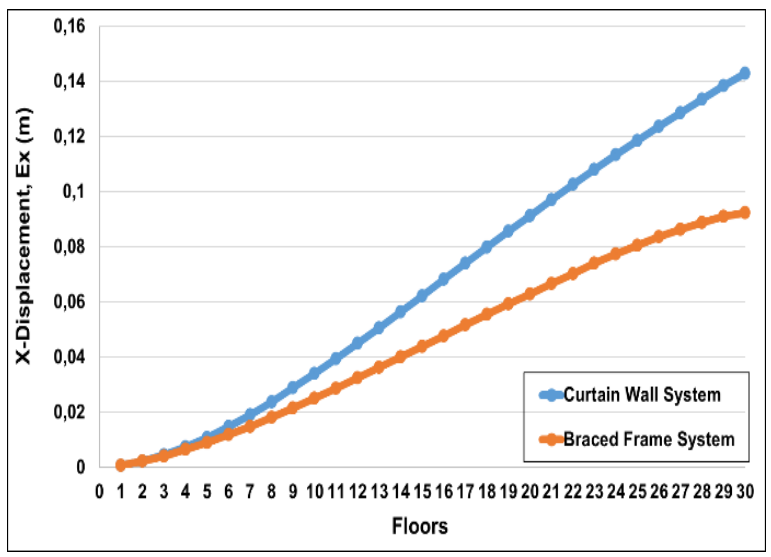

Figure 7. Graph of displacement values in $\mathrm{x}$ direction for each floor in 30-storey building models

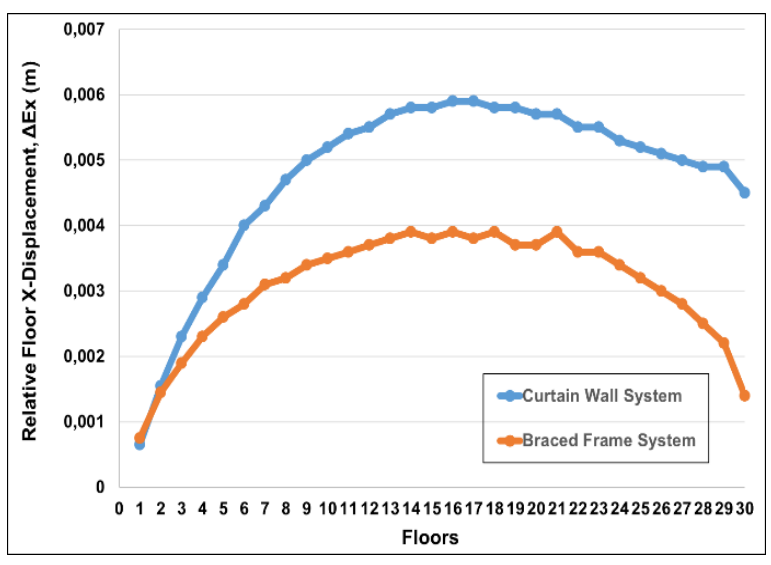

Figure 8. Graph of relative floor displacement values in $\mathrm{x}$ direction for each floor in 30-storey building models 
A similar situation to the results obtained in 20 storey building models is also seen for 30-storey building models. As seen in both graphs, the performance of braced frame systems against seismic movements in reinforced concrete buildings is better than the shear wall frame system (Figure 7 and 8).

The graphs of the comparisons in the analysis of the shear wall frame system and braced frame systems for 30-storey buildings are shown in Figure 9 and 10.

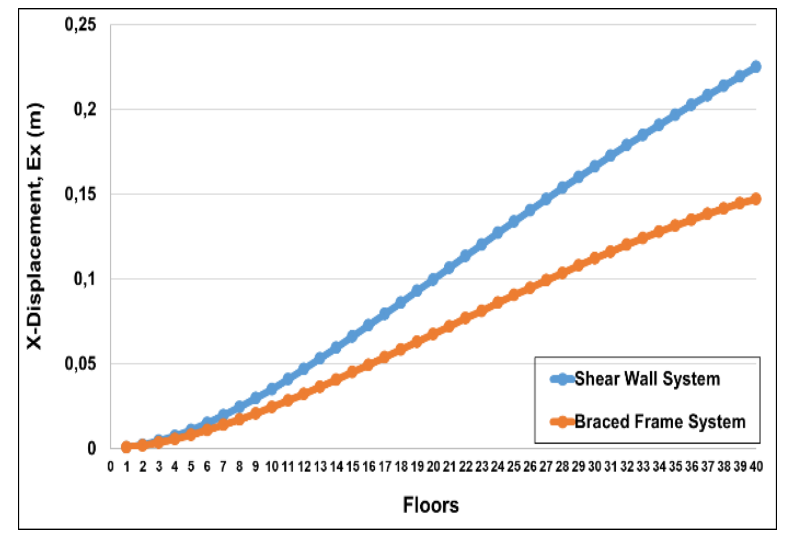

Figure 9. Graph of displacement values in x direction for each floor in 40-storey building models

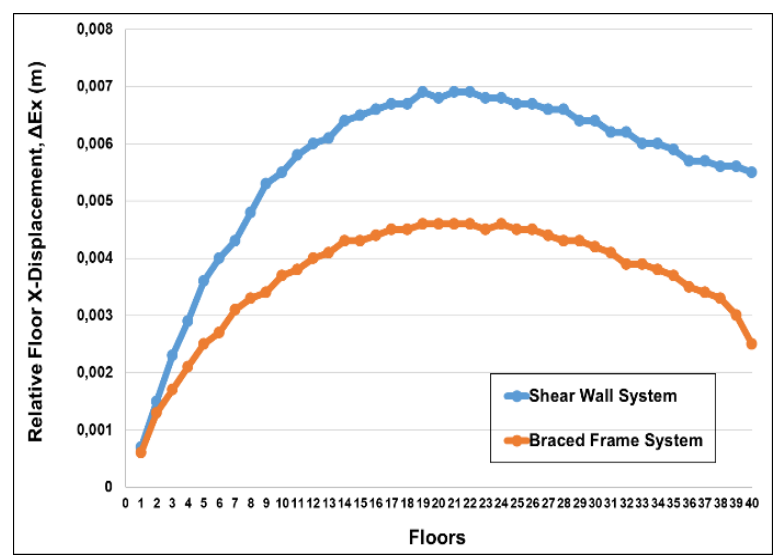

Figure 10. Graph of relative floor displacement values in $\mathrm{x}$ direction for each floor in 40-storey building models

It is seen that the braced frame system model performs better than the shear wall frame system model against seismic movements in 40-storey building models (Figure 9 and 10).

\section{CONCLUSIONS}

Improving the performance of multi-storey structures against seismic movements has been an important study topic for scientists and researchers. Especially, mitigation of the damage caused by destructive earthquakes on the structures is an issue that needs attention.

In this study, it has been indicated by modeling studies that reinforced concrete multi-storey buildings have a better performance against seismic movements by using the braced frame system, which is generally used in steel structures.

Model studies were carried out for 20-30 and 40 -storey reinforced concrete buildings. With the model outputs obtained, the displacement in the $\mathrm{x}$ direction cases of the braced frame system and the shear wall frame systems were examined.

As a result, it has been indicated as a result of the model studies that the braced frame system, which is not used in multi-storey reinforced concrete buildings, has a better performance against seismic movements than the shear wall frame system.

\section{ACKNOWLEDGEMENT}

This research paper prepared from the master thesis of Miraç Mesutoğlu.

\section{REFERENCES}

AFAD, Turkey Earthquake Risk Map (2018). https://deprem.afad.gov.tr/depremtehlikehari tasi?lang=en (Last Accessed: 20.01.2020).

Kayvani, K. (2014). Design of High Rise Buildings: Past, Present and Future. Eds. St Smith, 23rd Australasian Conference on the Mechanics of Structures and Materials (ACMSM23), vol.(1) pp. 15-20. ISBN: 9780994152008.

KeerthiGowda, B.S., Syed, T. (2014). Seismic Analysis of Multistorey Building with Floating Columns. Proceedings of the First Annual Conference on Innovations and Developments in Civil Engineering, ACIDIC-2014. India.

Kovacevic, I., Dzidic, S. (2018). High-Rise Buildings: Structures and Materials. International Burch University, Sarajevo.

Li, B. (2010). Enhancement of Structural Analysis of Multi-Storey Buildings by Integrating Nonstructural Components into Structural System. PhD Thesis, The University of Melbourne.

Nath, S., Debnath, N., \& Choudhury, S. (2018). Methods for Improving the Seismic Performance of Structures: A Review. In IOP Conference Series: Materials Science and Engineering 377(1):012141.

Phocas, M.C., \& Pamboris, G. (2009). Multi-storey structures with compound seismic isolation. Proceedings of earthquake resistant engineering structures VII. WIT Press, Southampton, UK, 207-216.

TBEC (2018). Turkey Building Earthquake Code, Republic of Turkey Ministry of Interior Disaster and Emergency Management Authority, Ankara, Turkey. 
Turkish Standard Institute (1997). Turkish Standard, TS498: The Calculation Values of Loads used in Designing Structural Elements. Ankara, Turkey, $21 \mathrm{p}$.
Turkish Standard Institute (2007). Turkish Standard, TS-EN-1991-1-4: Actions on structures - Part 1- 4: General actions - Wind actions, Ankara, Turkey, 122 p. 